\title{
Újraiparosodás és útfüggőség: gondolatok a magyarországi ipar területi dinamikája kapcsán
}

\section{Reindustrialisation and path-dependence: ideas related to the spatial dynamics of the Hungarian industry}

\author{
MOLNÁR ERNŐ, LENGYEL ISTVÁN MÁTÉ
}

MOLNÁR Ernő: egyetemi adjunktus, Debreceni Egyetem, Társadalomföldrajzi és Területfejlesztési Tanszék; molnar.erno@science.unideb.hu

LENGYEL István Máté: PhD-hallgató, Debreceni Egyetem, Társadalomföldrajzi és Területfejlesztési Tanszék; pityihun@hotmail.com

KULCSSZAVAK: újraiparosodás, útfüggőség, ipar - Magyarország

ABSZTRAKT: A hazai ipar térszerkezetének hosszabb távú fejlődése, illetve magasabb hozzáadott értéket eloállító tevékenységek felé tolódása (mely a hosszabb idő alatt kialakuló, nehezen reprodukálható helyspecifikus, minőségi telepítő tényezők felértékelődését hozza magával) indokolttá teszi a folyamatok hátterében húzódó, a fejlődés szervességét, folyamatosságát képviselő tényezők kutatását. Vizsgálataink elméleti keretbe helyezése érdekében az útfüggőség változásokra nyitottabb, dinamikus koncepciója felé fordultunk, amely a múlt döntéseinek a jelen és a jövő gazdasági fejlődését befolyásoló szerepét állítja a középpontba. Ennek hangsúlyozása mellett sem kívánjuk alulértékelni azon külső hatásokat, melyek főként a külföldi működőtőke-befektetések formájában az ország ipari szerkezetváltását befolyásolják. Másrészt, az empirikus kutatásaink helyszínét képező alföldi térségek jellemzője a hagyományos iparági körzetek hiánya, melyből adódóan az útfüggőség bezáródás problémáját kiemelo, statikusabb megközelítése kevésbé tűnik alkalmas vonatkoztatási rendszernek. Empirikus vizsgálatainkat kisvárosi és középvárosi közegben végeztük. Tapasztalataink szerint a befektetők számára kevésbé vonzó kisváros iparának átalakulásában a helyi meghatározottságok szerepe nagyobb, a külföldi tőkebefektetések révén érvényesülő hatások korlátozottabbak, és közvetett módon - a helyi vállalkozások beszállítói hálózatokba kapcsolódásán keresztül - jelennek meg. A középvárosi esettanulmányban szereplő, külföldi zöldmezős beruházások helyszínét képező ipari park esetében a helyi meghatározottságok szerepe mérsékeltebb, de mégis kitapintható a múltból örökölt adottságok befolyásoló hatása, az útfüggőség megjelenése.

Ernő MOLNÁR: assistant professor, Department of Social Geography and Regional Development Planning, Faculty of Science and Technology, University of Debrecen; molnar.erno@science.unideb.hu István Máté LENGYEL: PhD student, Department of Social Geography and Regional Development Planning, Faculty of Science and Technology, University of Debrecen; pityihun@hotmail.com

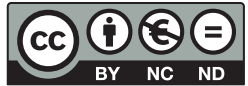


ABSTRACT: In our study we wish to demonstrate the mechanisms of path-dependence influencing the spatial development of industry. The study relies on case studies carried out in small and big town environments in a county of the Hungarian Great Plain which is considered to be relatively more successful in terms of industrial renewal.

The concept of path-dependence emphasizes the negative lock-in effect in an industrial district. But according to other researchers (particularly Martin 2009; Martin, Sunley 2010) this theory can also be used to explain the positive development of an industrial economy. We used mainly this approach.

However, it is also necessary to mention that the Hungarian Great Plain has never been an industrial district. As a consequence, we could neglect this element of the premises of the theory of path-dependence in this study.

The first case study focuses on the conversion of Hungarian-owned, medium-sized firms: Their market relations, product structure, technology and features of production organisation gradually changed with the adaptation to a new environment. Indirect effects enforced by supplier relationships (connected to transnational companies) contributed to this adaptation in addition to the circumstances inherited. The presence of relatively small foreign capital still increased the chances of a more radical restructuring, but since the role of these equity investments remained modest in Mezötur, the recent industrial development of the town is determined by the actors (and their constraints) rooted in the industry of the socialist period.

The second case study concentrates on the phenomenon of layering caused by foreign direct investments. There are no direct organisational and locational links between the greenfield investments in the industrial park established by the local government of Szolnok and the industrial heritage of the socialist period. However, the milieu which was built around the industries of the region played a detectable role in the location of firms - partly reproducing the inherited structure of industry. In this example, the influencing effects of the decisions made in the past on the present are represented by a qualified labour force (and the concomitant educational institutions), the locally produced raw materials and the physical infrastructure which served the former industrial base as it serves today's local economic actors.

The significance of the actors in the local economy of both towns investigated suggests that the concept of path dependence is worth more attention in research studies concerning domestic industrial geography. Our examples clearly show that the phenomenon cannot be interpreted only in terms of a dual economic structure, but has to be seen also in the light of foreign equity investments calling for more radical industrial restructuring. If we accept pathdependence as shaping the spatial structure of the Hungarian industry to a certain degree after the change of the political system, we can more easily see the questions related to the general adaptability of economic development strategies within the framework of re-industrialisation.

Therefore we intend to continue our research with an attempt to comprehend the opportunities and constraints of development and to interpret the transformation processes after the change of the political system within the context of labour-intensive, capital-intensive and technology-driven industries, as well as that of small and big town environments (including first and foremost: Debrecen) - focusing on the region of the Hungarian Great Plain.

\section{Bevezetés}

A magyarországi ipar térszerkezetének rendszerváltás utáni kutatásában - érthető módon - meghatározó szerepet játszott a változások beazonosítása és magyarázata (Barta 2002; Kiss 2010), miközben a téma kutatói kevesebb figyelmet fordítottak a változatlanságot képviselő elemek, valamint a hátterükben meghúzódó adottságok vizsgálatára. A régi és új struktúrák összekapcsolódása, to- 
vábbá az új struktúrák hosszabb távon is megfigyelhető viszonylagos területi változatlansága ugyanakkor azt sejteti, hogy stabilitás irányába mutató mechanizmusok is munkálkodnak a gazdasági átalakulás hátterében, melyek feltárása az ipar térbeliségének megértéséhez és az újraiparosodásra alapozott területfejlesztési elképzelések realitásának megítéléséhez elengedhetetlen. A globális termelési hálózatokba integrálódott hazai ipar hosszabb távú jövője a feljebb lépésben, a magasabb hozzáadott értéket képviselő tevékenységek felé történő elmozdulásban rejlik (Lux 2013a; Szalavetz 2012), amit az újraiparosodás szerkezeti vonásai többé-kevésbé alá is támasztanak (Barta, Czirfusz, Kukely 2008; Kuttor 2011). Ha elfogadjuk kiindulópontként e megállapítást, akkor belátható, hogy e folyamat a helyi környezetben gyökerező, hosszabb idő alatt kialakuló, nehezebben reprodukálható minőségi telepítő tényezők felértékelődését, ezzel együtt az egyes lokalitások örökölt adottságainak jelentőségnövekedését eredményezheti.

Nem kevesebbet állítunk tehát, mint hogy a jövő ipari telephelyeinek beazonosításához a múlt, illetve a jelen múlthoz füződő kapcsolatának vizsgálata értékes fogódzót szolgáltat. Írásunk az útfüggőség evolúciós gazdaságföldrajzban fontos szerepet játszó koncepciója köré épül (Boschma, Martin 2010). A téma elméleti pozicionálása és az alapfogalmak tisztázása után áttekintjük, hogy - kimondva vagy kimondatlanul - miként jelenik meg az útfüggőség gondolata a hazai ipari térszerkezeti kutatásokban. Külföldi és hazai szakirodalmi források feldolgozására épülő vizsgálatunkat az iparföldrajzi szempontból izgalmasnak tűnő, felértékelődő alföldi megyék közé sorolt Jász-Nagykun-Szolnok megyében (Nemes Nagy, Lőcsei 2015), kis- és középvárosi empíriával (vállalati interjúk, ipari parki esettanulmány) egészítjük ki. Azt vizsgáljuk, hogy miként befolyásolja a múlt öröksége az ipar aktuális pályafutását: megkíséreljük feltárni és térbeli kontextusban értelmezni az ágazat fejlődését alakító kumulatív folyamatokat. Bár a problémakör megjelenik más hazai írásokban (Keresnyei, Egedy 2015; Lengyel, Bajmócy 2013; Lux 2009, 2013a; Makó, Illésy 2008; Tóth 2012), területi összefüggéseinek kutatása mindeddig érintőleges: a cikk megírásával ezért célunk az útfüggőség kérdésével kapcsolatos hazai gazdaságföldrajzi diskurzus élénkítése is.

\section{Az útfüggőség koncepciója}

Az útfüggőség az evolúciós közgazdaságtan gondolatait területi kutatásokba integráló, a gazdaság hosszabb távú történeti fejlődésének fontosságát hirdető evolúciós gazdaságföldrajz egyik központi koncepciója. A fogalom a múlt eseményeinek és döntéseinek jelen, illetve jövő folyamataira gyakorolt hatását jelenti (Martin, Sunley 2010), mely rugalmasan értelmezendő: merev, a különböző alternatívákat kizáró cselekvéssorozat helyett inkább „útiterv”, ahol egy adott irány elérése felé a már „kitaposott” út követése kézenfekvőbbnek tűnik, 
mint a (bizonytalannak vélt) többi lehetőség (Walker 2000). Az útfüggőség különböző vizsgálati szinteken értelmezhető: egy-egy vállalat, iparág vagy régió egyaránt lehet közege (Martin, Sunley 2010). Miközben a magasabb szinteken értelmezett útfüggőség nem választható el az egyes szereplők tevékenységének meghatározottságától, a téma kutatói felhívják a figyelmet a vállalatok rövid távú és irreverzibilis döntéseinek, illetve az ágazatok és régiók hosszabb távú és visszafordítható fejlődési folyamatainak kettősségére (Schamp 2005).

Az evolúciós gazdaságföldrajz közgazdaságtani alapjait taglaló írásokban az útfüggőség hatásmechanizmusai három formában jelennek meg. Az útfüggőség jelenthet technológiai bezáródást: egy múltbéli cselekvéssor eredményeként sajátos technológiai pályaív alakul ki, melyről a közben felmerülő alternatív (esetleg hatékonyabb) technológiák ellenére sincs letérés. Másrészt az útfüggőséget agglomerációs hatások, pozitív externáliák is erősíthetik: a növekvő hozamok pozitív visszacsatolási folyamatokat generálnak, melyek megszilárdítják a korábban kialakított fejlődési pályákat. Harmadrészt útfüggőség irányába hat az intézményi hiszterézis: a fogalom a formális és informális intézmények, a társadalmi berendezkedés és a kulturális vonások időben önmagukat reprodukáló sajátosságára utal, mely elősegíti bizonyos tevékenységek stabilizálódását, társadalmi beágyazódását (Martin, Sunley 2006).

A szakirodalomban az útfüggőség értelmezése eltérő megközelítésekben jelenik meg. A Paul David és Brian Arthur nevéhez füződő, közgazdaságtani alapokon álló klasszikus modell a bezáródás és az egyensúlyi állapot jelenségére fókuszál. E stabilitást sugalló nézet - kritikusai szerint - nemcsak az evolúciós gondolat változás-központúságával áll ellentmondásban, de következetlen is: a fejlődési pályák létrejöttét véletlen események eredményeként írja le, és az útfüggőség hatásmechanizmusainak befolyásoló szerepét csupán a már kialakult fejlődési pálya formálásában ismeri el (Martin 2009). A folyamatos evolúció elvét képviselő politikatudományi és történeti szociológiai munkák ugyanakkor arra mutatnak rá, hogy a helyi gazdaság összetett entitás, melyben egyes komponensek folyamatos változáson mehetnek keresztül a többi összetevő szükségszerű módosulása nélkül. Az alkotóelemek egy részének változása hosszú távon az entitás egészének (szerkezeti, funkcionális, irányítási módot érintő) átalakulását eredményezheti, egyrészt az útfüggő fejlődési pályájáról történő letérés, másrészt a bezáródás, a stabil egyensúlyi állapot elérése nélkül. Egy új helyi iparág (gazdasági szereplő) megjelenése tehát nem pusztán történelmi véletlen vagy járulékos lehetőség: a folyamatot a korábbi helyi fejlődési pályákból átörökített, múltban kialakult erőforrások, kompetenciák és tapasztalatok befolyásolják (Martin 2009).

Az útfüggőség fogalma pozitív és negatív kontextusba egyaránt helyezhető. Az első eset a fogalom rugalmas, változásoknak inkább teret engedő megközelítését, illetve az új, dinamikus gazdasági tevékenységek - pozitív visszacsatolások által történő megerősítésének - mechanizmusait (klaszteralapú 
gazdaságfejlesztés) foglalja magába, míg a második opció a változatlanságot, a szerkezetváltás képességének hiányát (bezáródás) jelenti (Martin 2009). Utóbbi felfogást az iparágak klaszterizációjának pozitív hatásait egyoldalúan hangsúlyozó modern gazdaságföldrajz nézőpontjának kritikája hívta életre: annak a ténynek a felismerése, miszerint az iparágak földrajzi tömörülése bizonyos tényezők egybeesése esetén negatív hatást fejthet ki az innovativitásra, a megújulás képességére (Hassink 2010).

Az útfüggőség „hagyományos” korlátozó jellegű értelmezése a bezáródás fogalmára épül. Funkcionális bezáródás esetén a nagyvállalatok és beszállítóik között fennálló szoros vertikális kapcsolatok nehezítik az utóbbiaknak a magasabb hozzáadott értéket képviselő funkciók (K+F, marketing) kiépítésére irányuló lépéseit, miközben e tevékenységek hiánya (például válság idején) csökkenti az új piacok felé történő sikeres nyitás esélyeit. A kognitív bezáródás a munkaadók és munkavállalók fejében kialakult szektor- és körzetspecifikus narratívát jelenti: egy hosszú ideig meghatározó gazdasági tevékenységet akkor is térségük gazdasági bázisaként kezelnek az érintettek, ha az a trendek alapján már nem felel meg a realitásoknak. Végül, a politikai bezáródás a meghaladott gazdasági szerkezetű intézményi struktúrák ipari szerkezetváltását lassító, konzerváló hatását jelenti. Az intézményrendszer magába foglalja a politikai döntéshozókat, iparági szakszervezeteket, ernyőszervezeteket és ügynökségeket, nagyvállalatokat, továbbá a gazdasági szereplők viselkedését meghatározó normákat, írott és íratlan törvényeket (Grabher 1993; Schamp 2005).

Az útfüggőség változásokra nyitott megközelítésében kulcsszerepet játszik a rétegződés, a konverzió, valamint a rekombináció fogalma. A rétegződés a helyi vállalatok összetételének változását jelenti, mely új szereplők megjelenésének (spin-off cégek, új vállalkozások, a földrajzi egységbe kívülről betelepülők), illetve korábbiak megszűnésének, elvándorlásának eredőjeként áll elő. A folyamat a helyi gazdaság fejlődését megalapozó változatosság (eltérő termelési és innovációs profilok) generálása szempontjából fontos (Martin 2009). A konverzió az egyes gazdasági szereplők fejlettebb technológiákat és üzleti megoldásokat, valamint újabb, diverzifikáltabb termékszerkezetet felvonultató progresszív irányváltását jelenti: elsősorban a kívülről belépő vállalatok és tovagyürüző hatásaik okozzák, miközben a folyamat a lokális gazdaság technológiai és termékorientációjának teljes megváltozását idézheti elő. A rétegződés és a konverzió halmozott hatásaként az iparág hátterében álló helyi hálózati externáliák (humán erőforrás, beszállítók, támogató intézmények, közvetítő szervezetek) is változhatnak. Végül, a rekombináció - az előbbi folyamatok feltételeként - a korábbi fejlődési pályákhoz kötődő erőforrások és kompetenciák újradefiniálása (új elemekkel ötvözése), mely lehetővé teszi az új fejlődési utak felé történő irányváltásokat (Martin 2009).

Miután - a fenti hatásmechanizmusok alapján is - az útfüggőséget döntően helyspecifikus tényezők okozzák, indokolt a fogalom „helyfüggő” értelmezése 
(Martin, Sunley 2010): az útfüggő fejlődés helyről helyre eltérő módon valósul meg. A gazdaság útfüggő fejlődésének gondolata a térben egyenlőtlen gazdasági növekedés mechanizmusainak mélyebb megértését segítheti ágazati és területi megközelítésben egyaránt. Egyrészt magyarázatul szolgálhat arra, hogy bizonyos iparágak és technológiák miért adott térbeli egységben alakulnak ki és fejlődnek, illetve máshol miért nem; másrészt választ adhat a kérdésre, hogy egyes regionális gazdaságok miért képesek alkalmazkodni a piaci változásokhoz, míg mások nem: milyen tényezőkkel magyarázható hosszú távú sikerességük, avagy szerkezeti válságuk (Martin, Sunley 2010; Strambach 2010). Az útfüggőség kétféle (bezáródást hangsúlyozó „hagyományos” és változásokra nyitott „dinamikus”) megközelítését szemlélteti az 1. ábra. Mi az útfüggőség dinamikus megközelítésére építettük vizsgálatainkat. Egyrészt nem kívántuk alulértékelni azon drasztikus külső hatásokat, melyek - főként a külföldi működőtőke-befektetések formájában - az ország gazdasági átalakulását befolyásolták a rendszerváltás után, és mind technológiai, mind szervezeti oldalról nagymértékben hozzájárultak az ipar megújulásához. Másrészt az empirikus kutatásaink helyszínét képező alföldi térségekben a szocialista időszak örökségének egyik jellemzője - meglátásunk szerint - éppen a hagyományos iparági körzetek hiánya, melyből adódóan az utóbbiakra alkalmazott, a bezáródás problémáját középpontba állító statikusabb modell kevésbé tűnik alkalmas elméleti keretnek.

1. ábra: Az útfüggőség hagyományos és dinamikus modellje The traditional and dynamic approach of path-dependence

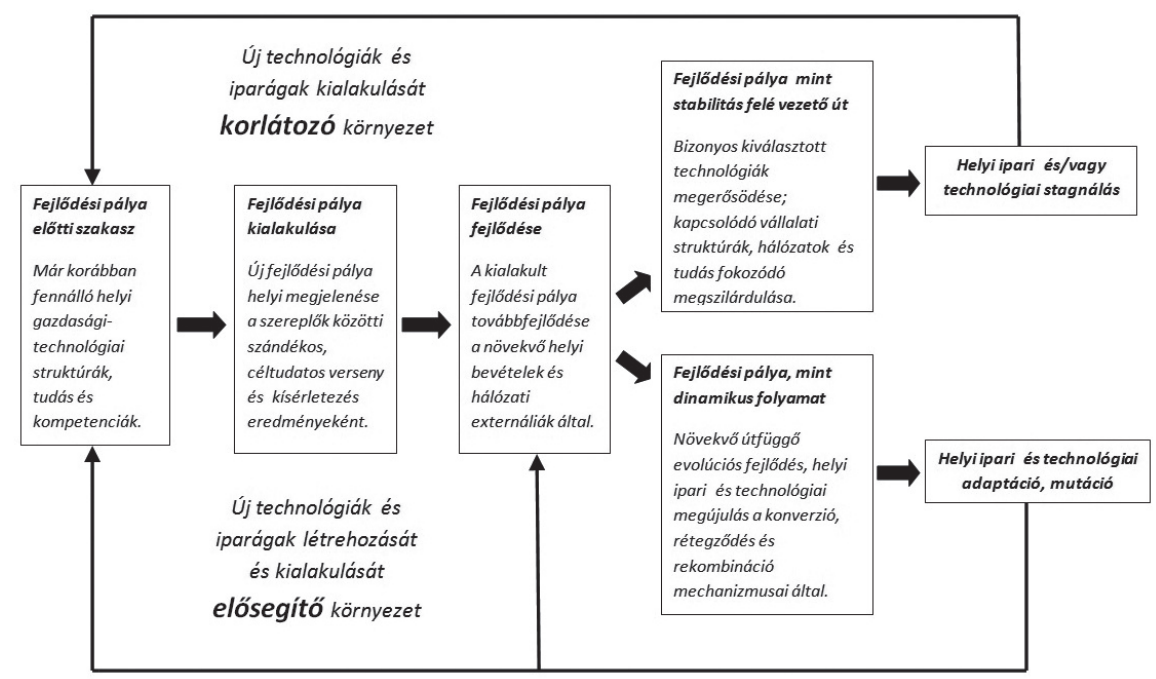

Forrás: Martin 2009 alapján. 


\section{Az útfüggőség megjelenése a hazai ipar térszerkezetének kutatásában}

A hazai ipar térszerkezetének rendszerváltás utáni fejlődését vizsgáló tanulmányok többnyire annak változását hangsúlyozzák. A megfigyelt folyamatok közül kiemelendő Budapest markáns dezindusztrializációja, ipari szerepeinek változása, illetve a fővárosi agglomeráció iparának súlyponteltolódása az elővárosok irányába, továbbá az észak-dunántúli térségek felértékelődése, melyet a korábbi ipari tengely keleti szárának elmélyülő szerkezeti válsága, Baranya megye iparának nagyarányú leépülése, illetve az alföldi megyék differenciálódása kísért. A területi változások gyökeres ágazati szerkezetváltással, a gépipar domináns iparággá válásával jártak együtt, miközben több térség ipara egysíkúvá vált (Barta 2002; Nemes Nagy, Lőcsei 2015). Akad olyan kutató, aki a jelenségek kapcsán a magyar ipar történetének eddigi legradikálisabb térszerkezeti változásáról írt (Kiss 2010).

Másrészt a korábbi iparvárosok fennmaradó, illetve megújuló ipari bázisa, több nagyváros (főként Győr és Székesfehérvár) megőrzött erős ipari funkciója, továbbá az Alföld és Dél-Dunántúl nagy részének relatív háttérbe szorulása az ipar rendszerváltás utáni átalakulása során a korábbi területi mintázat részbeni továbbélését sugallja. Hasonló benyomása van az eseményeket követő kutatónak, ha az újraiparosodás ezredforduló utáni területi kiterjedésével - elsősorban a korábbi ipari tengely keleti szárának felértékelődésével (2. ábra) - kiújulni látja az iparosodottság terén mutatkozó hagyományos észak-déli megosztottságot (Barta, Lőcsei 2011; Barta, Czirfusz, Kukely 2008; Kiss 2010; Nemes Nagy, Lőcsei

2. ábra: Újraformálódó ipari tengely: a változáson vagy a változatlanságon van a hangsúly? Renewal of the industrial axis: change or stability?

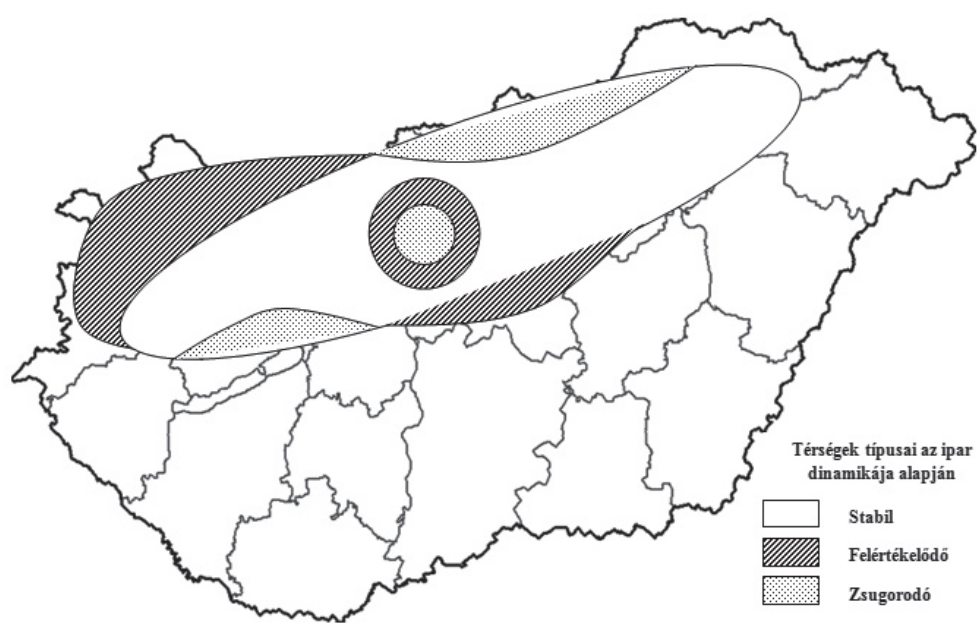

Forrás: Kiss 2010 alapján. 
2015). Felvetődik a kérdés, hogy az olyan „újszerü” helyeken megvalósuló óriásberuházások, mint a kecskeméti autógyár, képesek lehetnek-e a hazai ipar térszerkezetének látványos módosítására? A stratégiai ágazatnak tartott autóipar földrajzára vonatkozó vizsgálatok jelezték: a Kelet-Magyarországon élénkülő beruházások ellenére az ezredforduló óta arányaiban sem nyugat-keleti, sem észak-déli irányban nem történt lényeges eltolódás az iparág térszerkezetében (Molnár 2013a). Egy témában született másik hazai, de kelet-közép-európai kitekintést tartalmazó tanulmány is arra hívta fel a figyelmet, hogy a külföldi tőkebefektetések csak részben alakították át a járműgyártás térbeliségét (Hardi 2012).

Az ipar területi stabilitását megtestesítő elemek önmagukban is felvetik a rendszerváltás előtti és utáni struktúrák közti kapcsolat lehetőségét, de a térbeliség magyarázataiban is feltünnek az útfüggő fejlődést sugalló gondolatok. A múlthoz kötődő legkézenfekvőbb kapocs a megörökölt struktúrák szervezeti átalakulása és megváltozott keretek közötti növekedése. A felbomló többtelephelyes, egykori szocialista vállalatok romjain továbbélő szereplők (Barta 2002), a privatizáció keretében megjelent (külföldi) működő tőke térbeli egyenlőtlenségei (Rechnitzer 1998), továbbá a privatizáció és zöldmezős beruházások nyomán letelepült szereplők több lépcsőben végrehajtott későbbi kapacitásbővítései (Barta, Czirfusz, Kukely 2008, az autóipar kapcsán Molnár 2013a) e tényező jelentőségére utalnak. A múlthoz füződő kapcsolat fejeződik ki a meglévő vállalatok integrálásával, illetve egykori iparterületek átalakításával létrehozott barnamezős ipari parkok intézményében (Kiss 2013) is. Számos szerző tesz említést olyan helyi telepítő tényezőkről (képzett munkaerő, hagyományok, infrastruktúra), melyek iparági előzmények létét feltételezik (Barta 2002; Kiss 2010; Koltai 2006). Az ipar térszerkezetének alakításában - az újabb transznacionális vállalatok letelepülésében és a helyi beszállítók növekedésében - egyre jelentősebb szerepet játszik az agglomerálódás vagy a klaszteresedés folyamata (Barta 2002; Füzi, Gombos, Tóth 2012; Grosz 2006; Kiss 2010). Utóbbi tényező jelentőségét - különösen a dinamikus iparágak kitüntetett területének számító Észak-Dunántúlon - autóipari telephelyként funkcionáló ipari parkokban végzett kérdőíves vizsgálataink is alátámasztották (Molnár 2013b).

Az útfüggőség koncepciója - elsősorban Lux Gábor nevéhez kötődően - megjelent hazai városok és régiók gazdasági átalakulását vizsgáló tanulmányokban (Lux 2009, 2013b). Szerzőjük a nyugatról „importált” fogalmat a posztszocialista térgazdasági folyamatok értelmezésére alkalmasnak találja, és az egykori nehézipari térségek struktúraváltásának problémái kapcsán negatív, illetve új, perspektivikus gazdasági struktúrák megerősödését („kisebb nagyvárosok” gazdasági bázisának megújitása Győr, Miskolc és Pécs példáján) vizsgáló pozitív összefüggéseiben is használja. Indirekt utalásokat az útfüggő átalakulás jelenségére más, szűkebb térségek gazdasági átalakulását vizsgáló tanulmányokban (például Bakács, Czakó, Sass 2006; Lados, Kollár 2012; Marsa 2002; Nagy 2013; Rechnitzer 2014) is találni. Kevés ugyanakkor az olyan magyarországi tanulmány, amely részletekbe menően foglalkozna az útfüggőség hatásmechanizmu- 
saival: mi a továbbiakban a bemutatott elméleti koncepció gyakorlati példákon keresztüli értelmezésére teszünk kísérletet.

\section{A múlt ipari szereplőinek továbbélése - kisvárosi esettanulmány}

Első esettanulmányunk középpontjában alföldi kisvárosi ipari vállalkozások állnak. Körükben a szocialista időszakban jellemző a külső (főként budapesti) központoktól függő, a vállalatok belső munkamegosztásában élőmunka-igényesebb szegmensekre specializálódó, technológiai lemaradást mutató, piacai terén válságágazatokhoz és válságtérségekhez nagyban kötődő és ezért a rendszerváltás után komoly leépülést mutató részlegipar (Barta 2002). Észak-alföldi kisvárosok ipari vállalkozásai körében végzett korábbi kérdőíves felmérésünk - több mint 140 cég válaszai alapján - arra az eredményre jutott, hogy a szocialista időszak ipari örökségében gyökerező szereplők száma az ezredforduló után is számottevő, a múlthoz füződő kapcsolatok szerepe különösen a nagyobb vállalatok esetében jelentős (Molnár 2007). E tapasztalatok alapján úgy véljük, hogy tanulmányunk tanulságai általánosíthatók.

Példánk szereplői mezőtúri gépalkatrészgyártó cégek. Egyikük 1953-ban, tanácsi vállalatként (VILLGÉP) kezdte pályafutását, majd 1975-ben bekebelezte az iparágában meghatározó budapesti szereplő (KONTAKTA). Az elektromos tömegcikkeket és játékokat készítő cég idővel ipari nyomógombok és kapcsolóelemek gyártására szakosodott, és különböző hazai készülék- és berendezésgyártó cégek (EVIG, Ikarus, Lehel, Magyar Hajó- és Darugyár, SZIM) beszállítójává vált, valamint közvetlenül a szovjet piacra is szállított. Másik vállalatunk az Alföld dekoncentrált iparosításának hullámában, 1970-ben, a szintén budapesti KAEV (Könnyűipari Gépgyártó Vállalat) telepeként jött létre. Faipari, bőripari, textilipari gépeket és alkatrészeket, ipari kerekeket, székeket gyártott. Beszállítóként kapcsolódott a Hajdúsági Iparmüvek háztartási gépgyártásához, de csehszlovák és szovjet exportot is lebonyolított.

Mind a KONTAKTA, mind a KAEV jelentős munkaadónak számított a városban: az 1980-as években egyenként 400-500 főt foglalkoztattak (ugyanekkor a város ipara összesen mintegy 3000 fónek adott munkát). A két vállalat korábban nem létezett ipari kultúrát, új fejlődési pályát honosított meg Mezőtúron. A város iparának szerkezete ugyan diverzifikált maradt (a specializáció hiánya miatt sem beszélhetünk bezáródásról), de az útfüggőség mechanizmusai között fontos szerepet játszó pozitív visszacsatolási folyamatot látjuk abban, hogy kiépült a két cég munkaerő-utánpótlását biztosító helyi oktatási kínálat. Az iskolákkal együttműködve - más vállalatokkal együtt - a KONTAKTA és a KAEV is bekapcsolódott a fémipari szakmák (forgácsoló, géplakatos, hegesztő, szerszámkészítő) oktatásába.

A mezőtúri gépalkatrészgyártást - piacainak drasztikus zsugorodásával - komoly sokkhatás érte a rendszerváltás idején. Részben ebből adódóan, részben a 
1. táblázat: Az esettanulmányban szereplő mezőtúri cégek néhány jellemzője Some features of the enterprises in the Mezôtúr case study

\begin{tabular}{llc}
\hline \multicolumn{1}{c}{ Cégnév } & \multicolumn{1}{c}{ Fö tevékenység } & Létszám $\left(2015, f^{\prime \prime}\right)$ \\
\hline Hermann Mezőtúr Kft. & 2561. Fémfelület-kezelés & 43 \\
LEDFAK Kft. & 2611. Elektronikai alkatrész gyártása & 134 \\
RAFI Hungaria Kft. & 2790. Egyéb villamos berendezés gyártása & 488 \\
VA Elektronika Zrt. & 2712. Áramelosztó, szabályozó készülék gyártása & 39 \\
VART-Speciál Kft. & 2511. Fémszerkezet gyártása & 84 \\
\hline
\end{tabular}

Forrás: Creditreform Céginformáció.

piacgazdasági átalakulás „sodrában” a két vállalat szervezeti átalakuláson ment keresztül: privatizációjuk mellett egyes tevékenységeik önálló cégekbe szervezése, illetve kulcsembereik egy részének kiválása és vállalatalapítása is jellemző volt az 1990-es években. Mai öt nagyobb utódjuk közül négy hazai tulajdonú középvállalat, illetve egy vegyesvállalatként alakult, majd 100\%-ban külföldi tulajdonba került, nagyvállalattá növekedett szereplő emelhető ki. Főként az utóbbi felfutásának köszönhető, hogy együttesen ma sem foglalkoztatnak sokkal kevesebb embert e cégek, mint elődeik az 1980-as években (1. táblázat). Rétegződési folyamatként is értelmezhető szervezeti átalakulásuk nem hozott gyökeres ipari szerkezetváltást. Az utódvállalatok megtartották gépalkatrészgyártó profiljukat: beszállítókként globális termelési hálózatokba integrálódtak, változatos hozzáadott értéket tartalmazó tevékenységeik fém alkatrészek, elektromechanikus komponensek, villamos berendezések, később elektronikai termékek gyártására terjedtek ki.

A zsugorodó piacok problémájának kezelése érdekében az átalakult cégek vezetői és az új vállalkozással indult szereplők nagyban támaszkodtak korábbi kapcsolataikra. Az „egyenes ági leszármazottnak” számító vállalkozások elsősorban háztartási gépgyártáshoz füződő kapcsolataikat tudták kiaknázni. Az üzleti partner (hűtőgépgyár) átalakulása sikeres volt, az új külföldi tulajdonosok Magyarországot relokációs célterületként kezelték, ahol nemcsak európai termelési kapacitásaik jelentős részét koncentrálták, de stratégiájukat a termelési folyamat mind több lépésének környékbeli beszállítókhoz történő kihelyezésére építették (Bakács, Czakó, Sass 2006). A váltás meghatározottságát jelzi, hogy egy transznacionális vállalat beszállítójává válás - a személyes kapcsolatokon és cégek közötti ajánlásokon alapuló megrendelések jelentőségnövekedésével - a vállalat több üzeméhez és a vállalatcsoport több cégéhez történő kapcsolódás esélyét is megnövelte (Dometic, Electrolux, Flymo, Husqvarna számára szállított hűtőgép-, mosógép-, porszívó-, tűzhely- és fünyíróalkatrészek). Az új cégek alapítása is a korábbi piaci kapcsolatok bázisán történt (a német Klöckner-Möller - ma Eaton Industries - és RAFI cégekkel még az 1990-es évek elején került kapcsolatba az elődvállalat). Másrészt idővel valamennyi cégnél megfigyelhető a felvevőpiacok több-kevesebb sikerrel végrehajtott diverzifikációja (autóipar, építőipari állványgyártás, gépgyártás): a rendszerváltás előtti tevékenységek kifutásának fokoza- 
tosságára jó példát kínál egyik alanyunk, akinél az örökölt termékek 2000-ben még 20\%-át, 2009-ben már csak 2\%-át tették ki az árbevételnek.

A múltból örökölt tényezők technológiai téren is hatással vannak az utódok működésére. Az „egyenes ági leszármazottak” esetében az 1980-as évek - átmenetileg visszaesést is mutató - technológiai színvonala egyrészt meghatározza, hogy mely iparágakban és tevékenységekben tudnak versenyképes ajánlatot tenni, másrészt befolyásolja termelésük hatékonyságát, s így a csekély árréssel működő beszállítói megrendelésekből realizálható profitok nagyságát. Vállalkozásaink a nyugati technológiai fölény és a keleti alacsonyabb nyersanyag-, energia- és bérköltségek szorításában kísérelnek meg érvényesülni, s ennek megfelelően a hosszabb távú trendek a kisebb szériákban gyártott, nagyobb hozzáadott értéket tartalmazó, rugalmas kapcsolattartást igénylő termékek felértékelődését mutatják termékszerkezetükben, amihez jelentős technológiai igények is társulnak. Pályázati pénzekből vagy saját forrásból megvalósuló technológiai fejlesztéseik részben a hátrányok lefaragását, részben - nem feltétlenül a legkorszerűbb alapokon - új kompetenciák kiépítését célozzák. Akad kifejezetten innovatív beruházás is: új piacok meghódítása érdekében kevéssé elterjedt, de perspektivikus technológia meghonosítása (fém felületkezelő cég autóipari beszállítók körében keresett cink-nikkel bevonata). A termelésszervezés korszerüsítése is megemlítendő, melyet a vizsgált cégek körében leglátványosabban a minőségbiztosítási rendszerek korai bevezetése fémjelez.

3. ábra: Legalább 10 főt foglalkoztató, helyi székhelyủ ipari vállalkozások iparágak szerinti megoszlása Mezőtúron (1998, 2013,\%)

Sectoral structure of local manufacturing enterprises in Mezötúr with at least 10 employees (1998, 2013, \%)

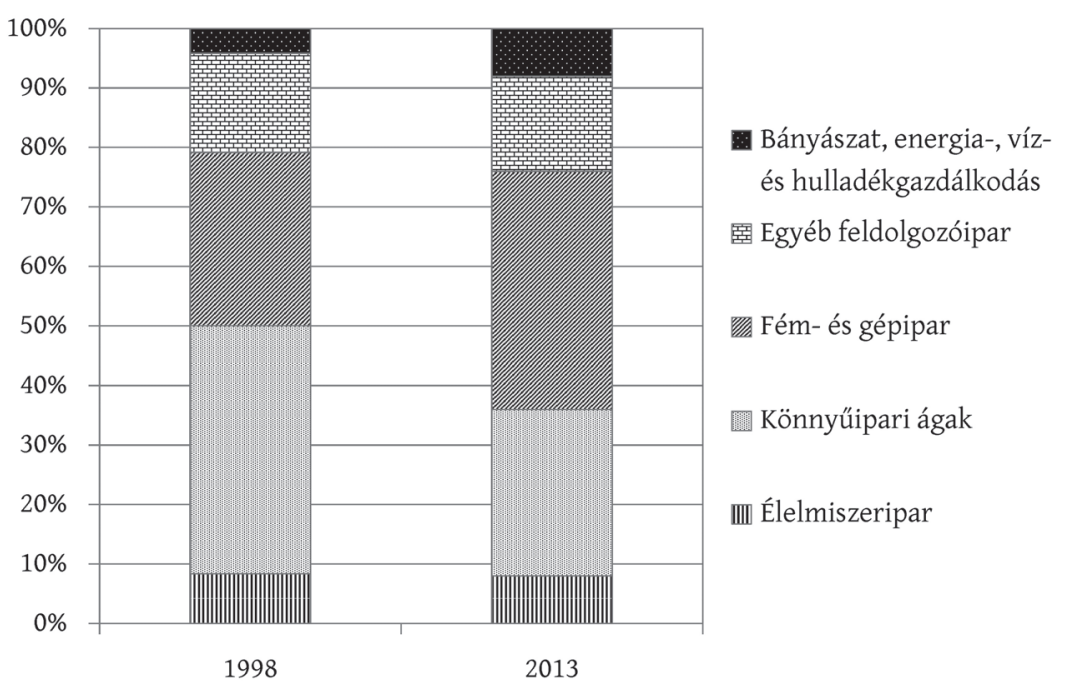

Forrás: Cég-Kód-Tár adatai alapján. 
A piaci kapcsolatok, a termékszerkezet, a technológia és a termelésszervezés fokozatos változása - a helyi humánerőforrás-utánpótlás valamennyi cégnél szóvá tett korlátai ellenére - konverzióra utal az egyes cégeknél, melyben jelentős szerepet játszik a rekombináció: a megörökölt képességek és a kívülről - a képző szervezetek szolgáltatásain vagy a beszállítói kapcsolatokon keresztül - becsatornázott ismeretek, inputok ötvözése. Elsősorban az utóbbi terén látjuk előnyösebb helyzetben lévőnek a külföldi tulajdonba került céget, amely minden tekintetben a legradikálisabb szerkezetváltást valósította meg (autóipar felé nyitás, elektromechanikai komponensgyártás helyett más nagyságrendet és technológiai hátteret képviselő elektronikai ipar, német hatékonyságú munkaszervezés). A külföldi tőkebefektető megjelenése ugyanakkor nem volt véletlenszerü: a korábbi üzleti kapcsolatok értek előbb vegyesvállalattá, majd zöldmezős vállalatalapítássá. A vizsgált cégek által foglalkoztatottak létszáma a 2011. évi népszámlálás mezőtúri ipari-építőipari dolgozóinak közel 40\%-át teszi ki: relatív súlyuk az ezredforduló óta - több iparág (tégla- és cserépgyártás, kerámiaipar, textil- és ruházati ipar, cipőgyártás) zsugorodásával - növekedett. A város ipari vállalkozásai körében látványos a könnyüipar le-, illetve a fém- és gépipar felértékelődése (3. ábra).

\section{Régi iparágak bázisán körvonalazódó újraiparosodás - középvárosi esettanulmány}

Második esettanulmányunk egy zöldmezős keretek között kialakított, alföldi középvárosi ipari park betelepülését elemzi. A vizsgált település Szolnok, melynek diverzifikált ipari öröksége a 19. századtól több szakaszban kibontakozó iparosítás következménye. A környék mezőgazdasági termékeit feldolgozó élelmiszeripara (cukoripar, húsipar, tejüzem), könnyűipara (a Tisza közelségére épülő fafeldolgozás, bútorgyártás és papíripar, élőmunka-igényes ruházati ipar), gépgyártása (vasúti csomópontba települt jármüjavító, mezőgazdasági gépgyártás), az 1950-es évek nehézipari beruházásainak keretében alapított vegyipara, illetve fazekasiparát, valamint tégla- és cserépgyártását kiegészítő épületelemgyára egyaránt említést érdemel (Szurmay 1975; Tóth 1993). A megyeszékhely szomszédságában elhelyezkedő Törökszentmiklóson és Martfün további élelmiszer-feldolgozó üzemek (malom-, baromfi-, növényolajipar, sörgyártás), mezőgazdasági gépgyár és az ország egyik legnagyobb cipőgyára helyezkedtek el (Tóth 1993; Volter 1999). A három város szekunder szektorban dolgozó alkalmazottainak létszáma közel 30 ezer fő́t tett ki a rendszerváltás idején. E tekintélyes ipari háttér az ezredforduló utáni évtizedben indult látványosabb leépülésnek, ami helyi szinten indokolttá tette a gazdasági bázis megerősítésére irányuló stratégiák kidolgozását.

E folyamatnak vált központi letéteményesévé a Szolnok önkormányzata által 1999-ben alapított, 2000-ben ipari park címmel felruházott, zöldmezős be- 
ruházások vonzására építő létesítmény, melynek közel 100 hektáros területe napjainkra gyakorlatilag teljesen ki van osztva. Bár a cégek betelepülése, illetve kapacitásbővítése még folyamatban van, a már működő, továbbá a betelepülés előrehaladott állapotába került szereplők vizsgálata érdekes tanulságokkal szolgálhat. A mintegy $23 \mathrm{db}$, területet vásárló cég nagy része kisvállalkozás, de néhány közepes és nagyméretű vállalat alapvetően meghatározza az ipari park profilját. Jellemzően külföldi tulajdonban lévő iparvállalatok települtek meg, melyeknek így a helyi ipari előzményekből - szervezeti szinten - levezethető kapcsolataik nincsenek. Az ipari park ugyan a szocialista időszakban kialakított iparterület folytatásában jött létre, de azzal területi átfedést nem mutat, így a telephely vonatkozásában sem jelenik meg a múlt örökségére épülés.

Figyelemre méltó ugyanakkor a szereplők ágazati hovatartozása: a vasúti jármügyár, a bőr- és fémipari tevékenységeket végző autóipari beszállítók, a papírgyár (tervezett cellulózgyár), valamint a hosszú ideje az előkészítés stádiumában álló citromsavgyár példája azt mutatja, hogy a városba települt külső szereplők a rendszerváltás előtti, hagyományos iparszerkezethez közel álló tevékenységeket alapítottak Szolnokon (2. táblázat). (Az 1970-es évek közepén az ipari dolgozók mintegy felét hat darab, ezer fö feletti létszámot foglalkoztató vállalat - a vasúti járműjavító, a mezőgazdasági gépgyár, a vegyiművek, a papírgyár, a cukorgyár és a betonelemgyár - jegyezte: Szurmay 1975.) Ezért szolnoki vizsgálataink elsősorban a külső szereplők által meghatározott, rétegződésként értelmezhető jelenség mozgatórugóinak feltárására irányultak: alapkérdésünk, hogy a betelepülő cégek telephelyválasztásában milyen mértékben játszottak szerepet olyan tényezők, melyek léte a korábbi fejlődési pályához köthető.

Tapasztalataink szerint a külföldi cégek telephelyválasztását befolyásoló tényezők egy része túlmutat a helyi adottságokon: kelet-közép-európai leányvállalat-alapításukat nagyban motiválta a költségcsökkentés, valamint a felvevőpiacok közelébe település igénye. Az országon belüli telephelyválasztásban ugyanakkor Szolnok - korábbi ipari kultúrájából levezethető - lokális adottságai is bizonyíthatóan szerepet játszottak, melyek közül a képzett munkaerő és annak reprodukcióját biztosító helyi oktatási intézmények, az örökölt gazdasági szerkezethez kötődő infrastruktúra, illetve a hagyományos tevékenysé-

2. táblázat: A Szolnoki Ipari Park jelenlegi és potenciális nagy foglalkoztatói Large present and potential employers of the Szolnok Industrial Park

\begin{tabular}{llr}
\hline \multicolumn{1}{c}{ Cégnév } & \multicolumn{1}{c}{ Fö tevékenység } & \multicolumn{1}{c}{ Létszám (2015, fó) } \\
\hline BBCA Szolnok Biokémiai Zrt. & 2014. Szerves vegyi alapanyag gyártása & építése folyamatban \\
BSM Magyarország Kft. & 2562. Fémmegmunkálás & 405 \\
Eagle Ottawa Hungary Kft. & 1512. Táskafélék, szíjazat gyártása & 2011 \\
Ecseri Kft. & 2453. Könnyüfémöntés & (30 Szolnokon) 185 \\
F. Segura Hungária Kft. & 2932. Közúti jármü alkatrészeinek gyártása & 130 \\
Stadler Szolnok Kft. & 3020. Vasúti, kötöttpályás jármü gyártása & 346 \\
\hline
\end{tabular}

Forrás: Szolnoki Ipari Park Kft. / Creditreform Céginformáció. 
gek - újabb betelepülők számára telepítő tényezőként szolgáló - produktumai érdemelnek említést.

A munkaügyi központtól származó információink szerint ugyan a legnagyobb munkaerőigényt jegyző cégek (Eagle Ottawa, BSM Magyarország, Stadler Szolnok, F. Segura) jelentős részben szakképzettséget nem igénylő munkakörökkel jelentek meg a helyi munkaerőpiacon (bőrkikészítő és feldolgozógép kezelöje, betanított fémmegmunkáló, betanított hegesztő- és présgépkezelő), de magasabb képzettséget igénylő tevékenységek (szakképzett bőr- és textilszabász, fémmegmunkáló, szerszámkészítő, gépésztechnikus, gépészmérnök) is szerepelnek álláskínálatukban. A Stadler vasúti kocsiszekrénygyártó üzemének elindulását a szükséges létszámú alumíniumhegesztő szakmunkás kiképzése előzte meg, melyre a város műszaki szakközépiskolájában került sor (a középfokú gépészeti oktatás komoly tradíciókkal rendelkezik Szolnokon, ráadásul hagyományos specializációja a vasútgépészet). A cég oktatási célú együttmüködés résztvevője: a kereskedelmi és iparkamara adatai szerint - cikkünk írása idején - három műszaki szakiskolás hegesztő képzése folyik a vállalatnál. A Stadler ugyanakkor nem egyedüli szereplője a vasúti járműgyártásnak Szolnokon, hiszen a MÁV járműjavítója továbbra is a város egyik legjelentősebb ipari munkaadója. A korábbi ipari kultúra jelen fejlődési folyamatait befolyásoló szerepét hangsúlyozó hipotézisünkre az Eagle Ottawa esetében a szabászok martfüi cipőipar és szolnoki bőripar közötti mozgása a bizonyíték.

A humán tényező jövőbeli felértékelődését, a meglévő adottságok és tudás új kontextusban történő rekombinációjának növekvő fontosságát valószínűsíti a szolnoki vállalkozások funkcionális feljebb lépése (termék- és tevékenységszerkezetük változása konverzióként értelmezhető). A Stadler 2009-ben indult alumínium kocsiszekrénygyártó üzeme idővel nemcsak kapacitásbővítésen ment keresztül, de 2013-tól forgóváz-revíziós központtal is bővült. Hasonló fejlődés figyelhető meg az Eagle Ottawa autóipari bőrtermékeket eloállító gyárában is: 2001-től szabászüzem, 2004-től festő̈uzem, 2009-től európai K+F-központ, 2017-től - a tervek szerint - bőr üléshuzatokat varró üzem működik Szolnokon. Az üléshuzatok varrásának Szolnokra telepítésével erősödhet a térség hagyományos bőripari kompetenciáinak kiaknázása, bár a cég jövőbeli igényeinek, illetve a foglalkoztatottak képzettségi szerkezetének pontos megismerése további terepi kutatásokat igénylő kérdés.

Útfüggőséget erősítő mechanizmusok megjelenését látjuk a kínai-magyar beruházás keretében tervezett citromsavgyár telephelyválasztásában. Miután a vegyipari alapanyag - beruházó technológiája szerinti - előállítása sok kukoricát igényel (mintegy 100 ezer tonna kukoricát dolgozna fel és évente 60 ezer tonna citromsavat gyártana az üzem), és ilyen mennyiségben a nyersanyag mozgatása jelentős költségeket jelent, kukoricával - támaszkodva a térség szántóföldi gabonatermelő tradícióira - Szolnok környezetéből látnák el. Ugyancsak fontos adottság a korábban kiépített ipari kapacitások által előállított nyersanyag telepítő tényezőként játszott szerepe: a Tiszamenti Vegyimü- 
4. ábra: Legalább 10 főt foglalkoztató, helyi székhelyủ ipari vállalkozások iparágak szerinti megoszlása Szolnokon (1998, 2013, \%)

Sectoral structure of local manufacturing enterprises in Szolnok with at least 10 employees (1998, 2013, \%)

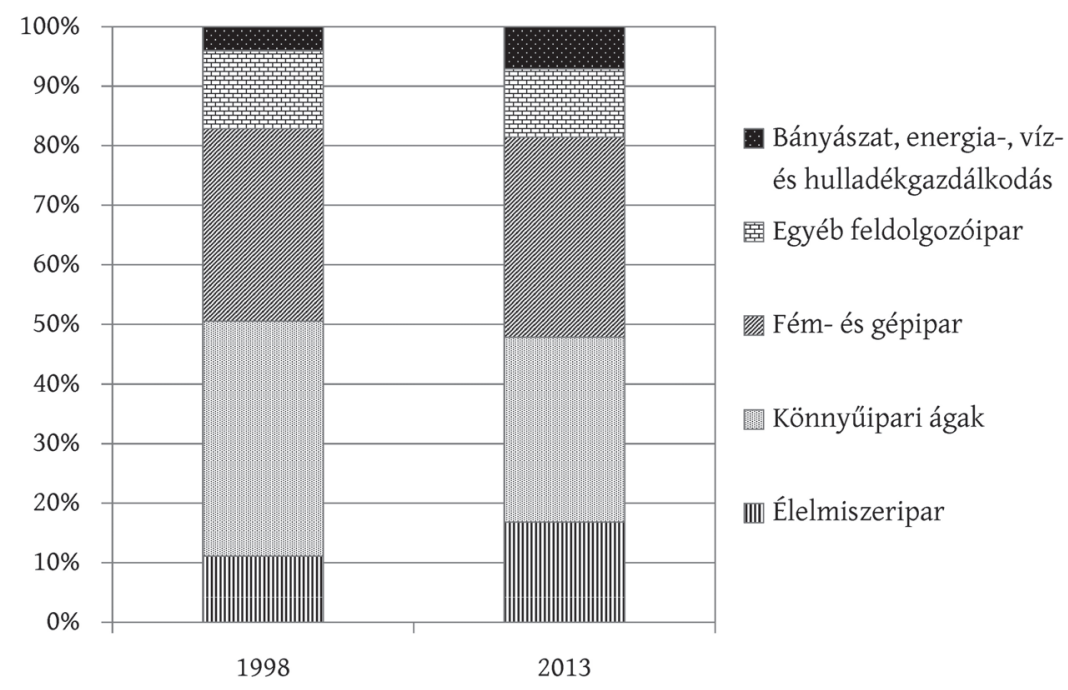

Forrás: Cég-Kód-Tár adatai alapján.

vek (Bige Holding) szomszédban elhelyezkedő kénsavgyárából a citromsavgyártás alapanyagának szállítása csővezetéken viszonylag egyszerűen megoldható. Nemcsak a tervezett vegyi üzem, de az ipari park területére települt papírgyár számára is fontos az iparivízigények kielégíthetősége: ennek alapját - a Tisza természeti adottságain kívül - a szocialista időszak infrastrukturális beruházásai (papírgyár, cukorgyár és vegyiművek vízkivételi művei) alapozták meg. Akad ellenpélda is: bár a város iparosodásában valaha fontos szerepet játszott vasúti csomópontja, ezen adottságát jelenleg még a vasúti járműgyártó Stadler sem használja ki.

A kiemelt cégek foglalkoztatása ma a 2011. évi népszámlálás szolnoki ipari és építőipari dolgozóinak 30\%-át teszi ki, de a városban megvalósult ipari zöldmezős beruházások domináns részét képviseli. A jelentősebb ipari vállalkozások körében a könnyüipar erős szerepvesztése, illetve az élelmiszeripar térnyerése figyelhető meg (4. ábra).

\section{Összegzés}

Az Alföld egyik ipari megújulását tekintve sikeresebbnek számító megyéjéből, kisvárosi és középvárosi közegből származó esettanulmányaink segítségével az ipar területi fejlődését befolyásoló útfüggőség érvényesülését kívántuk érzékel- 
tetni. Vizsgálatunk az útfüggőség változásokra nyitott dinamikus megközelítésére épült, melyet egyrészt a külföldi működőtőke-befektetések hazai ipari szerkezetváltást nagymértékben felgyorsító szerepének elismerése, másrészt a bezáródás problémájával leginkább azonosított hagyományos iparági körzetek - az empirikus kutatásaink helyszínét képező Alföldön jellemző - hiánya indokolt.

Első esettanulmányunk középpontjában hazai tulajdonú, közepes méretű cégek konverziója állt: piaci kapcsolataik, termékszerkezetük, technológiájuk és termelésszervezési jellemzőik a külső környezethez történő alkalmazkodás jegyében fokozatosan változtak, melyekhez örökölt adottságaik mellett (transznacionális vállalatokhoz füződő) beszállítói kapcsolatokon keresztül érvényesülő közvetett hatások járultak hozzá. A kisebb helyi meghatározottságú külföldi tőke jelenléte növelte a radikálisabb szerkezetváltás esélyét, de miután Mezőtúron e tőkebefektetések szerepe mindvégig mérsékelt maradt, napjainkban is a szocialista időszak iparában gyökerező szereplők (és korlátaik) határozzák meg a város iparának fejlődését.

Második esettanulmányunk a külföldi tőkebefektetések közreműködésével generált rétegződés jelenségére fókuszált: a szolnoki önkormányzat ipari parkjában megvalósult zöldmezős beruházások és a szocialista időszak ipari öröksége között közvetlen szervezeti és telephelyi kapcsolat ugyan nem áll fenn, de a hagyományos iparszerkezetet részben reprodukáló cégek megtelepülésében kimutatható szerepet játszott a térség iparágai köré épült miliö. E példában a megfelelő képzettségű munkaerő (oktatási intézmények), a korábbi ipari bázist kiszolgáló fizikai infrastruktúra, továbbá a telepítő tényezőként szolgáló nyersanyagokat előállító helyi gazdasági szereplők képviselik számunkra a múlt döntéseinek jelenre gyakorolt hatását.

A vizsgált szereplők helyi gazdaságon belüli jelentős súlya mindkét város esetében jelzi, hogy az útfüggőség problémája nagyobb figyelemre érdemes a hazai iparföldrajzi kutatásokban. Példáink szemléletesen mutatják, hogy a jelenség nemcsak a duális gazdasági szerkezet - több korláttal bíró - hazai kis- és középvállalkozásokat tartalmazó oldalán értelmezhető, hanem a radikálisabb ipari szerkezetváltással kecsegtető külföldi tőkebefektetések esetében is. Ha elfogadjuk az útfüggőség valamilyen mértékủ szerepét a hazai ipar rendszerváltás utáni térszerkezetének alakításában, akkor könnyen beláthatjuk az újraiparosításra építő gazdaságfejlesztési stratégiák általános adaptálhatóságával kapcsolatos kérdőjeleket is.

Ezért is kívánjuk folytatni kutatásainkat, melyek keretében - elsősorban az Alföld területére fókuszáltan - egyrészt élőmunka-, illetve tőke- és technológiaigényes iparágak, másrészt kis- és nagyvárosi térségek (köztük mindenekelőtt Debrecen) rendszerváltás utáni átalakulásának értelmezésére, fejlesztési lehetőségeik és korlátaik megragadására teszünk kísérletet. 


\section{Köszönetnyilvánítás}

A publikáció a Bolyai János Kutatási Ösztöndíj támogatásával készült.

\section{Irodalom}

Bakács A., Czakó V., Sass M. (2006): Beszállítók és hálózatosodás: az Electrolux Lehel Kft. példája. Külgazdaság, 7-8. 44-59.

Barta Gy. (2002): A magyar ipar területi folyamatai 1945-2000. Dialóg Campus Kiadó, Budapest, Pécs

Barta Gy., Czirfusz M., Kukely Gy. (2008): Újraiparosodás a nagyvilágban és Magyarországon. Tér és Társadalom, 4., 1-20.

Barta Gy., Löcsei H. (2011): The effect of the recent economic crisis on the spatial structure of Hungarian industry. Regional Statistics, 14. (Special Issue), 99-109.

Boschma, R., Martin, R. (2010): The aims and scope of evolutionary economic geography. In: Boschma, R., Martin, R. (eds.): The handbook of evolutionary economic geography. Edward Elgar, Cheltenham, Northampton, 3-39. http://doi.org/88c

Füzi A., Gombos Sz., Tóth T. (2012): Járműipari telepítési tényezők Kelet-Közép-Európában. In: Rechnitzer J., Smahó M. (szerk): Jármüipar és regionális versenyképesség. Universitas-Győr Nonprofit Kft., Győr, 143-163.

Grabher, G. (1993): The weakness of strong ties; the lock-in of regional development in the Ruhr-area. In: Grabher, G. (ed.): The embedded firm: On the socioeconomics of industrial networks. Routledge, London, New York, 255-277.

Grosz A. (2006): Clusterisation processes in the Hungarian automotive industry. Hungarian Academy of Sciences, Centre for Regional Studies, Pécs (Discussion Papers; 52.)

Hardi T. (2012): A közúti jármügyártás szerepe a kelet-közép- és délkelet-európai ipari térségek kialakulásában. In: Rechnitzer J., Smahó M. (szerk): Jármúipar és regionális versenyképesség. Universitas-Győr Nonprofit Kft., Győr, 99-108.

Hassink R. (2010): Locked in decline? On the role of regional lock-ins in old industrial areas. In: Boschma, R., Martin, R. (eds.): The handbook of evolutionary economic geography. Edward Elgar, Cheltenham, Northampton, 450-468. http://doi.org/88d

Keresnyei K., Egedy T. (2015): Adalékok a kreatív gazdaság elméletéhez. Földrajzi Közlemények, 1., $30-42$.

Kiss É. (2010): Területi szerkezetváltás a magyar iparban 1989 után. Dialóg Campus Kiadó, Budapest, Pécs

Kiss É. (2013): Sokszínủ ipari parki állomány. In: Kiss É. (szerk.): A hazai ipari parkok különböző dimenzióban. Dialóg Campus Kiadó, Budapest, Pécs, 11-39.

Koltai Z. (2006): A magyar lakosság és vállalati szféra lakó-, illetve telephelyválasztásának szempontjai. Területi Statisztika, 3., 240-254.

Kuttor D. (2011): Az ipari szerkezetváltás területi hatásai a visegrádi országokban. Észak-magyarországi Stratégiai Füzetek, 2., 94-103.

Lados M., Kollár K. (2012): A helyi gazdaságfejlesztés és a járműipar Győr példáján. In: Rechnitzer J., Smahó M. (szerk): A jármúipari beszállitói hálózat Kelet-Közép-Európában és Magyarországon. Universitas-Győr Nonprofit Kft., Győr, 262-285.

Lengyel B., Bajmócy Z. (2013): Regionális és helyi gazdaságfejlesztés az evolúciós gazdaságföldrajz szemszögéből. Tér és Társadalom, 1., 5-29.

Lux G. (2009): Az ipar hagyományos terei: a régi ipari térségek. Tér és Társadalom, 4., 45-60.

Lux G. (2013a): Az ipari parkok a területi versenyképességben: telephelyek vagy fejlesztési csomópontok? In: Kiss É. (szerk.): A hazai ipari parkok különböző dimenzióban. Dialóg Campus Kiadó, Budapest, Pécs, 294-309. 
Lux G. (2013b): Kritikus tömeg alatt: a fejlesztési együttmüködés lehetőségei a kisebb nagyvárosokban. Tér és Társadalom, 4., 52-74.

Makó Cs., Illésy M. (2008): Gazdasági modernizáció Magyarországon: félúton az „útfüggőség” és az „új fejlődési pálya teremtése között"? In: Makó Cs. (szerk.): Az új fejlődési utak lehetőségei a tanuló gazdaságban: a rugalmasság és biztonság átalakuló jelentései. Debreceni Egyetem, Debrecen, 49-66.

Marsa A. (2002): Kecskemét, a Dél-Alföld „kistigrise” és a külföldi működőtőke-beruházások. Külgazdaság, 5-6., 53-75, illetve 59-73.

Martin, R. (2009): Rethinking regional path dependence: Beyond lock-in to evolution. Papers in Evolutionary Economic Geography. Utrecht University, Utrecht

Martin, R., Sunley, P. (2006): Path dependence and regional economic evolution. Journal of Economic Geography, 6., 395-437. http://doi.org/bqmk6q

Martin, R., Sunley, P. (2010): The place of path dependence in an evolutionary perspective on the economic landscape. In: Boschma, R., Martin, R. (eds.): The handbook of evolutionary economic geography. Edward Elgar, Cheltenham, Northampton, 62-92. http://doi.org/88f

Molnár E. (2007): Megújulás vagy csendes vegetálás? Az észak-alföldi kisvárosok feldolgozóipara az ezredfordulón. Doktori (PhD) értekezés. Debreceni Egyetem, Debrecen

Molnár E. (2013a): Egy dinamikus iparág foglalkoztatási hatásainak földrajzi aspektusai: a magyarországi autóipar esete. Területi Statisztika, 4., 322-339.

Molnár E. (2013b): Az autóipar mint húzóágazat az ipari parkokban: telephelyválasztás, közlekedési adottságok. In: Kiss É. (2013): A hazai ipari parkok különböző dimenzióban. Dialóg Campus Kiadó, Budapest, Pécs, 210-235.

Nagy G. (2013): A Békés megyei ipari parkok, különös tekintettel a közlekedési adottságokra. In: Kiss É. (2013): A hazai ipari parkok különböző dimenzióban. Dialóg Campus Kiadó, Budapest, Pécs, 127-143.

Nemes Nagy J., Lőcsei H. (2015): Hosszú távú megyei ipari növekedési pályák (1964-2013). Területi Statisztika, 2., 100-121.

Rechnitzer J. (1998): A privatizáció regionális összefüggései. Kulturtrade Kiadó Kft., Budapest

Rechnitzer J. (2014): A győri gazdaság pályapontjai a rendszerváltozástól napjainkig. In: Lados M. (szerk.): A gazdaságszerkezet és vonzáskörzet alakulása. A Győri Járműipari Körzet, mint a térségi fejlesztés új iránya és eszköze c. kutatás monográfiái 5., Universitas-Győr Nonprofit Kft., Győr, 104-129.

Schamp, E. W. (2005): Decline of the district, renewal of firms: an evolutionary approach to footwear production in the Pirmasens area, Germany. Environment and Planning A, 4., 617-634. http://doi.org/dpgsx8

Strambach, S. (2010): Path dependence and path plasticity: the co-evolution of institutions and innovation - the German customized business software industry. In: Boschma, R., Martin, R. (eds.): The handbook of evolutionary economic geography. Edward Elgar, Cheltenham, Northampton, 406-431. http://doi.org/88g

Szalavetz A. (2012): A „feljebb lépési“ teljesítmény mérése a globális értékláncokon belül. Külgazdaság, 3-4., 66-86.

Szurmay E. (szerk.) (1975): Szolnok, a Közép-Tiszavidék tájszervező centruma. Verseghy Ferenc Megyei Könyvtár, Szolnok

Tóth B. I. (2012): Regionális rugalmasság - rugalmas régiók. Tér és Társadalom, 2., 3-21.

Tóth J. (szerk.) (1993): A szolnoki agglomeráció. MTA Regionális Kutatások Központja, Pécs

Volter E. (1999): A szolnoki agglomeráció nagyvállalatai az átmenet időszakában. Földrajzi Értesito”, 3-4., 333-353.

Walker, R. (2000): The geography of production. In: Sheppard, E., Barnes, T. (eds): A companion to economic geography. Blackwell, Oxford, 113-132. 